\title{
Application of The Group Investigative Model and Concrete Media to Improve Science Learning Outcomes For Fifth Grade Students
}

\author{
Azmi Zakiyya Pratami \\ Universitas Sebelas Maret. \\ azmizakiyya@student.uns.ac.id
}

\section{Article History}

received 30/4/2021

revised 30/5/2021

accepted 30/6/2021

\begin{abstract}
Application Group Investigation Learning Model with Concrete Media to Improve Science Learning Outcomes on the Theme of Events in the Lives of Fifth Grade Students at SD Negeri Karangasem 1 Academic Year 2020/2021. The purpose of this study is to describe the application Group Investigation learning model with concrete media to improve science learning outcomes on the Events in Life theme. This research is a classroom action research which was conducted for three cycles. The subjects of this study were the fifth grade students of SD Negeri Karangasem 1 for the 2020/2021 academic year. Data collection techniques used are observation, interviews, and tests. The validity of the data using triangulation techniques and sources. Data analysis was carried out through data reduction, data presentation, and drawing conclusions. The results showed that the application Group Investigation learning model with concrete media could improve science learning outcomes on the Events in Life theme.
\end{abstract}

Keywords: Natural Sciences, Group Investigation, Concrete Media, Learning Outcomes.

\begin{abstract}
Abstrak
Penerapan Model Pembelajaran Group Investigation dengan Media Konkret untuk Meningkatkan Hasil Belajar IPA pada Tema Peristiwa dalam Kehidupan Peserta Didik Kelas V SD Negeri Karangasem 1 Tahun Ajaran 2020/2021. Tujuan penelitian ini, yaitu mendeskripsikan penerapan model pembelajaran Group Investigation dengan media konkret untuk meningkatkan hasil belajar IPA pada tema Peristiwa dalam Kehidupan. Penelitian ini merupakan penelitian tindakan kelas yang dilaksanakan selama tiga siklus. Subjek penelitian ini adalah peserta didik kelas V SD Negeri Karangasem 1 tahun ajaran 2020/ 2021. Teknik pengumpulan data yang digunakan yaitu observasi, wawancara, dan tes. Validitas data menggunakan triangulasi teknik dan sumber. Analisis data dilaksanakan melalui reduksi data, penyajian data, dan penarikan kesimpulan Hasil penelitian menunjukkan bahwa penerapan model pembelajaran Group Investigation dengan media konkret dapat meningkatkan hasil belajar IPA pada tema Peristiwa dalam Kehidupan.
\end{abstract}

Kata kunci: IImu Pengetahuan Alam, Group Investigation, Media Konkret, Hasil Belajar. 


\section{PENDAHULUAN}

Pada abad ini, pendidikan menjadi fokus utama dalam upaya menjamin kualitas siswa yang memiliki kecakapan dan keterampilan abad 21. Berbagai upaya dilakukan oleh pemerintah untuk mempersiapkan serta menyediakan generasi terdidik yang berkualitas dan sesuai dengan kebutuhan abad 21 . Salah satu tantangan nyata dunia pendidikan di abad 21 adalah mampu menghasilkan sumber daya manusia yang memiliki kompetensi utuh yang dikenal dengan kompetensi abad 21. Kompetensi abad ke-21 merupakan kompetensi utama yang harus dimiliki siswa agar mampu berkiprah dalam kehidupan nyata pada abad 21. Menurut Kemendikbud (2017: 5), kompetensi keterampilan abad 21 yang harus dimiliki siswa atau yang biasa dikenal dengan 4C yaitu: kreativitas dan inovasi (creativity and innovation), berpikir kritis dan pemecahan masalah (critical thinking and problem solving), komunikasi (communication), dan kolaborasi (collaboration).

Kompetensi abad 21 sudah mulai ditanamkan pada siswa di jenjang pendidikan dasar yang terintegrasi dalam berbagai muatan pembelajaran. IPA merupakan salah satu muatan pelajaran yang tepat untuk menanamkan dan mengembangkan kompetensi keterampilan abad 21. Pembelajaran IPA mengedepankan sikap ilmiah atau perilaku ilmiah seperti jujur, disiplin, tanggung jawab, santun, peduli, dan percaya diri kepada siswa. Dalam pembelajaran IPA, implementasi sikap ilmiah atau perilaku ilmiah diwujudkan melalui sebuah interaksi yaitu kolaborasi (collaboration) atau kerja sama dengan keluarga, teman, guru, dan tetangganya guna memecahkan masalah dalam kehidupan sehari-hari (Kemendikbud, 2013: 101). Jadi, keterampilan kolaborasi (collaboration) atau kerja sama dengan teman sebaya, keluarga dan lingkungan dalam muatan pelajaran IPA merupakan hal penting yang harus dimiliki siswa dalam mewujudkan salah satu kompetensi $4 \mathrm{C}$ di abad 21. Namun pada kenyataannya kerja sama siswa masih menjadi kendala dalam pembelajaran terutama dalam proses pembelajaran daring.

Kaitannya dengan pelaksanaan pembelajaran daring IPA di Sekolah Dasar, peneliti melakukan wawancara dengan guru kelas V di SD N Karangasem 1. Hasil wawancara menunjukkan adanya kondisi sebagai berikut: (1) metode pembelajaran yang biasa digunakan dalam pembelajaran IPA adalah metode penugasan via WAG, (2) media yang digunakan adalah video pembelajaran yang dikirimkan melalui WAG, (3) kerjasama siswa masih rendah karena tidak menggunakan metode diskusi, (4) pada saat pembelajaran rata-rata siswa pasif bertanya, dan (5) hasil belajar IPA siswa kelas $\mathrm{V}$ tergolong rendah.

Guna memperkuat hasil wawancara peneliti juga melakukan analisis data hasil belajar siswa untuk mengetahui tingkat keberhasilan belajar siswa. Analisis data penilaian akhir semester pada muatan IPA tahun ajaran 2020/ 2021 terdapat 44,12\% atau 15 siswa dari 34 siswa yang mendapatkan nilai di bawah KKM. Nilai KKM yang ditentukan sekolah untuk muatan IPA adalah 75.

Rendahnya nilai siswa tersebut diduga karena (1) Penerapan model pembelajaran yang kurang bervariatif, (2) Media pembelajaran yang digunakan kurang bervariatif (3) Rasa ingin tahu siswa pada pelajaran IPA masih rendah, karena siswa jarang bertanya kepada guru, (4) dalam proses pembelajaran tidak terdapat diskusi kelompok.

Bedasarkan permasalahan yang telah dipaparkan di atas, peneliti menetapkan untuk menggunakan model pembelajaran kooperatif tipe group investigation sebagai upaya untuk meningkatkan hasil belajar siswa. Pembelajaran kooperatif membawa konsep inovatif, dan menekankan keaktifan siswa, juga diharapkan dapat meningkatan hasil belajar siswa (Susanto, 2014: 199). Group investigation menurut Trianto (Susanto, 2014: 235) adalah tipe pembelajaran kelompok yang melibatkan siswa dalam perencanaan baik dari topik yang akan dipelajari dan bagaimana jalannya penyelidikan mereka. 
Langkah-langkah menerapkan model pembelajaran Group Investigation menurut Cristina \& Kristin (Mustofa, Slameto, dan Radia, 2018: 28) ada 6 tahap yaitu: (1) pembentukan kelompok; (2) menentukan tema yang akan di bahas; (3) melakukan investigasi; (4) membuat laporan tertulis; (5) presentasi kelompok; dan (6) evaluasi/penilaian. Tembang, T., Harmawati, D., Raharjaan, J.P., (2019: 236) telah membuktikan bahwa model pembelajaran kooperatif tipe Gl dapat meningkatkan hasil belajar IPA. Hal ini sejalan dengan pendapat Susanto (2014: 199) bahwa pembelajaran kooperatif membawa konsep inovatif yang dapat meningkatan hasil belajar siswa.

Selain itu dalam Penerapan Group Investigation harus dikombinasikan dengan media yang sesuai dan melibatkan interaksi siswa dalam penggunaanya. Pemilihan media harus memperhatikan karakteristik siswa. Media konkret merupakan media yang sesuai untuk siswa kelas V SD karena anak pada usia Sekolah Dasar (SD) membutuhkan benda konkret sebagai media pembelajaran agar tujuan pembelajaran dapat tercapai lebih optimal. (Fatimah, F.N, 2013: 3). Penggabungan Group Investigation dengan media konkret dapat menjadi perantara untuk menemukan pesan atau informasi dalam proses pembelajaran yang dapat merangsang pikiran, perasaan, perhatian dan kemauan siswa sehingga dapat mendorong terjadinya proses belajar pada diri siswa (Yuliana \& Budianti, 2015: 36). Media konkret yang digunakan oleh peneliti dalam peneletian ini berupa macam-macam benda padat, cair, dan gas yang digunakan untuk kegiatan percobaan perubahan wujud benda. Melalui media konkret, berbagai perubahan wujud benda akibat kalor dapat diamati dan dibuktikan oleh siswa secara lebih nyata melalui percobaan dan diskusi kelompok sehingga hasil pembelajaran akan lebih bermakna.

Adapun penelitian Arsita, D.R., Dibia, I.K., dan Sukmana, A (2020:268) dengan penelitian berjudul "Peningkatan Hasil Belajar IPA melalui Model Pembelajaran Group Investigation Berbantuan Media Konkret" menunjukan bahwa model pembelajaran Group Investigation berbantuan media konkret terbukti dapat meningkatkan hasil belajar IPA siswa.

Penelitian ini bertujuan untuk 1) Mendeskripsikan penerapan model pembelajaran Group Investigation dengan media konkret untuk meningkatkan hasil belajar IPA pada tema peristiwa dalam kehidupan di kelas V SD N Karangasem 1 tahun ajaran 2020/ 2021, 2) Meningkatkan hasil belajar IPA pada tema peristiwa dalam kehidupan di kelas V SD N Karangasem 1 tahun ajaran 2020/ 2021 melalui penerapan model pembelajaran Group Investigation dengan media konkret, 3) Mendeskripsikan kendala dan solusi dalam penerapan model pembelajaran Group Investigation dengan media konkret untuk meningkatkan hasil belajar IPA pada tema peristiwa dalam kehidupan di kelas V SD N Karangasem 1 tahun ajaran 2020/ 2021.

\section{METODE}

Pendekatan yang digunakan dalam penelitian ini yaitu Penelitian Tindakan Kelas (PTK). Jenis data pada penelitian tindakan kelas ini ada dua macam, yaitu data kualitatif berupa informasi mengenai pelaksanaan pembelajaran IPA menggunakan model pembelajaran Group Investigation dengan media konkret dan data kuantitatif berupa nilai hasil belajar siswa pada pembelajaran IPA pada tema Peristiwa dalam Kehidupan. Sumber data dalam penelitian ini yaitu guru selaku peneliti dan peserta didik kelas $\mathrm{V}$. Teknik pengumpulan data menggunakan observasi, wawancara, dan tes hasil belajr siswa. Uji validitas data dilakukan dengan triangulasi teknik dan triangulasi sumber data. Analisis data meliputi reduksi data, penyajian data, dan penarikan kesimpulan sesuai model analisis data menurut Miles dan Huberman (Sugiyono, 2012, pp.337-345).

Penelitian ini dinyatakan berhasil jika penerapan langkah- langkah model pembelajaran group Investigation yang diukur melalui observasi dan wawancara 
pelaksanaan tindakan dapat memenuhi indikator kinerja penelitian dengan persentase $85 \%$ dan ketuntasan hasil belajar setelah menerapkan model pembelajaran group investigation yang diukur dengan tes hasil belajar siswa dapat mencapai persentase $85 \%$ dengan Kriteria Ketuntasan Minimal $(\mathrm{KKM})=75$.

Penelitian ini dilakukan selama tiga siklus. Setiap siklus terdiri dari satu kali pertemuan. Tahapan dalam siklus terdiri atas empat tahap yaitu perencanaan, pelaksanaan, pengamatan, dan refleksi.

\section{HASIL DAN PEMBAHASAN}

Penerapan model pembelajaran group Investigation dengan media konkret untuk meningkatkan hasil belajar siswa kelas V SD N Karangasem 1 dilakukan dalam tiga siklus. Setiap siklus terdiri dari satu pertemuan.

Proses pembelajaran dilaksanakan dengan langkah-langkah sebagai berikut: (1) membentuk kelompok; (2) mengidentifikasi topik; (3) merencanakan investigasi; (4) melaksanakan investigasi; (5) menyiapkan laporan akhir; (6) mempresentasikan laporan akhir, dan (7) evaluasi. Langkah-langkah pembelajaran model group Investigation tersebut mengacu pada langkah-langkah yang dikemukakan oleh Mustofa, Slameto, dan Radia (2018: 28), Taniredja, Faridli, dan Harmianto (2014: 7778), dan Susanto (2014: 237) yang kemudian disimpulkan menjadi langkah yang sudah disebutkan di atas.

Hasil observasi penerapan model group Investigation dengan media konkret mengalami peningkatan pada setiap siklusnya hingga mencapai kinerja penelitian yang ditargetkan sebesar $85 \%$.

Tabel 1. Persentase Hasil Observasi Guru dan Siswa Siklus I,II, dan III

\begin{tabular}{|c|c|c|c|}
\hline \multirow{2}{*}{$\begin{array}{c}\text { Penerapan Model group } \\
\text { Investigation dengan media } \\
\text { konkretSiklusIIIIIIGuruPersenta } \\
\text { se } \\
\text { (\%)84.5285.7190.17SiswaPerse } \\
\text { ntase (\%)77.3884.8287.05 } \\
\end{array}$} & \multicolumn{3}{|c|}{$\begin{array}{c}\text { SiklusIIIIIIGuruPersentase } \\
\text { (\%)84.5285.7190.17SiswaPersentase } \\
\text { (\%)77.3884.8287.05 }\end{array}$} \\
\hline & $\begin{array}{c}\text { IIIIIGuruPerse } \\
\text { ntase } \\
\text { (\%)84.5285.71 }\end{array}$ & $\begin{array}{c}\text { IIIIIGuruPersen } \\
\text { tase } \\
(\%) 84.5285 .71\end{array}$ & $\begin{array}{c}\text { IIIGuruPersent } \\
\text { ase } \\
\text { (\%)84.5285.71 }\end{array}$ \\
\hline $\begin{array}{c}\text { GuruPersentas } \\
\mathrm{e} \\
(\%) 84.5285 .71\end{array}$ & $\begin{array}{c}\text { 84.5285.7190. } \\
\text { 17SiswaPerse } \\
\text { ntase } \\
\text { (\%) } 77.3884 .82\end{array}$ & $\begin{array}{l}\text { 85.7190.17Sis } \\
\text { waPersentase } \\
(\%) 77.3884 .82\end{array}$ & $\begin{array}{c}\text { 90.17SiswaPer } \\
\text { sentase } \\
(\%) 77.3884 .82\end{array}$ \\
\hline $\begin{array}{l}\text { SiswaPersenta } \\
\text { se } \\
\text { (\%) } 77.3884 .82\end{array}$ & $\begin{array}{c}77.3884 .8287 . \\
05\end{array}$ & 84.8287 .05 & 87.05 \\
\hline
\end{tabular}

Berdasarkan Tabel 1, persentase rata-rata hasil observasi guru pada siklus I yaitu $84.52 \%$. Siklus II meningkat menjadi $88.71 \%$ dan siklus III menjadi $90,17 \%$. Hasil observasi siswa pada siklus I dengan persentase $77.38 \%$, mengalami peningkatan pada siklus II menjadi $84.82 \%$ dan siklus III menjadi $87.05 \%$.

Tabel 2. Hasil belajar IPA siswa Siklus I, II, dan III

\begin{tabular}{|c|c|c|c|}
\hline $\begin{array}{c}\text { Hasil belajar IPA } \\
\text { siswaSiklus ISiklus IISiklus } \\
\text { IIITuntasPersentase } \\
\text { (\%)79.4182.3488.24Belum } \\
\text { TuntasPersentase } \\
\text { (\%)20.5917.6611.76 }\end{array}$ & $\begin{array}{l}\text { Siklus } \\
\text { ISiklus } \\
\text { IISiklus } \\
\text { IIITuntas }\end{array}$ & $\begin{array}{l}\text { Siklus } \\
\text { IISiklus } \\
\text { IIITuntas }\end{array}$ & $\begin{array}{l}\text { Siklus } \\
\text { IIITuntas }\end{array}$ \\
\hline
\end{tabular}




\begin{tabular}{|c|c|c|c|c|}
\hline $\begin{array}{c}\text { TuntasPer } \\
\text { sentase } \\
(\%) 79.418 \\
2.3488 .24\end{array}$ & $\begin{array}{c}\text { Persentase } \\
\text { (\%)79.4182.348 } \\
\text { 8.24Belum } \\
\text { TuntasPersenta } \\
\text { se } \\
(\%) 20.5917 .661 \\
1.76\end{array}$ & $\begin{array}{r}79.4182 \\
3488.24\end{array}$ & $\begin{array}{c}82.3488 . \\
\text { 24Belum } \\
\text { TuntasP } \\
\text { ersentas } \\
\text { e } \\
(\%) 20.5 \\
917.661 \\
1.76\end{array}$ & $\begin{array}{c}\text { 88.24Bel } \\
\text { um } \\
\text { TuntasPe } \\
\text { rsentase } \\
\text { (\%)20.59 }\end{array}$ \\
\hline $\begin{array}{l}\text { Belum } \\
\text { TuntasPer } \\
\text { sentase } \\
(\%) 20.591 \\
7.6611 .76\end{array}$ & $\begin{array}{c}\text { Persentase } \\
\text { (\%)20.5917.661 } \\
1.76\end{array}$ & $\begin{array}{r}20.5917 . \\
6611.76\end{array}$ & $\begin{array}{c}17.6611 \\
76\end{array}$ & 11.76 \\
\hline
\end{tabular}

Berdasarkan tabel di atas, dapat disimpulkan bahwa ketuntasan hasil belajar IPA siswa pada tema Peristiwa mengalami peningkatan. Pada siklus I persentase ketuntasan siswa yaitu $79.41 \%$. siklus II persentase ketuntasan yaitu $82.34 \%$. Sedangkan pada siklus III meningkat menjadi $88,24 \%$. Berdasarkan hasil observasi dan wawancara, guru berhasil menerapkan langkah langkah model Group Investigation dan media konkret dan siswa dapat mengikuti pembelajaran dengan baik.

Dengan demikian penerapan model Group Investigation dengan media konkret dapat meningkatkan hasil belajar siswa yang dapat dilihat dari persentase siswa yang memenuhi ketercapaian target dari siklus I-III. Hasil penelitian ini memperkuat penelitian yang dilakukan Primasari, E (2017:140) yang berjudul "Peningkatan Keaktifan dan Hasil Belajar Kognitif IPA melalui Group Investigation di SD Negeri 3 Sirau"

Kendala dalam penelitian ini ada 6 yaitu: (1) guru kurang memberikan pernyataan pemantik kepada siswa untuk memancing siswa bertanya; (2) siswa belum percaya diri dan kurang termotivasi untuk mengajukan pertanyaan; (3) terdapat sebagian siswa yang belum berdiskusi dengan teman kelompok; (4) beberapa siswa kekurangan waktu untuk menyelesaikan laporan; (5) siswa belum memahami perannya dalam kelompok sehingga guru lebih aktif memandu jalannya diskusi dalam WAG; (5) guru belum menunjuk semua kelompok untuk melakukan persentasi atau menanggapi; (6) siswa belum membagi peran atau kedudukan saat persentasi.

Kendala wajar ditemui karena siswa belum terbiasa menggunakan model pembelajaran Group Investigation. Kendala ini disebabkan salah satunya merupakan kelemahan dari Group Investigation yang dikemukakan oleh Ibrahim (Masjudin, 2016: 78) yang mengemukakan bahwa model group investigation merupakan model yang sulit dan kompleks untuk dilakukan.

Sedangkan solusi dari kendala tersebut yaitu: (1) guru lebih banyak memberikan pernyataan pemantik kepada siswa dengan bahasa yang mudah dipahami; (2) guru memberikan dorongan dan motivasi kepada siswa untuk bertanya dengan percaya diri; (3) guru memberikan dorongan kepada siswa supaya berdiskusi dalam WAG; (4) Guru memberikan waktu yang lebih lama untuk menyelesaikan laporan; (5) guru memotivasi siswa supaya memahami perannya dan tidak ragu untuk aktif dalam diskusi kelompok; (6) guru mencatat kelompok yang sudah aktif dan menunjuk kelompok yang belum berperan aktif dalm persentasi maupun menanggapi teman yang sedang persentasi; (6) memotivasi siswa untuk percaya diri dan aktif dalam mengikuti pembelajaran.

\section{SIMPULAN}

Model pembelajaran Group Investigation dengan media konkret untuk meningkatkan hasil belajar IPA pada tema Peristiwa di Sekitarku di kelas 5 SD Negeri Karangasem 1 tahun ajaran 2020/ 2021 dilaksanakan dengan langkah-langkah 
sebagai berikut: (1) membentuk kelompok; (2) mengidentifikasi topik; (3) merencanakan investigasi; (4) melaksanakan investigasi; (5) menyiapkan laporan akhir; (6) mempresentasikan laporan akhir; dan (7) evaluasi.

Penerapan model pembelajaran Group Investigation dengan media konkret dapat meningkatkan hasil belajar IPA pada tema Peristiwa di sekitarku di kelas V SD Negeri Karangasem 1 tahun ajaran 2020/ 2021.

Berkaitan dengan hasil penelitian yang telah dicapai, terdapat implikasi secara praktis, yaitu penelitian ini dapat dijadikan dasar bagi guru untuk menentukan model pembelajaran untuk meningkatkan hasil belajar siswa. Salah satu model yang tepat adalah model pembelajaran Group Investigation. dengan media konkret.

\section{DAFTAR PUSTAKA}

Arsita, D.R., Dibia, I.K., dan Sukmana, A. (2020). Peningkatan Hasil Belajar IPA Melalui Model Pembelajaran Group Investigation Berbantuan Media Konkret. Jurnal Penelitian dan Pengembangan Pendidikan, 4 (2), 268.

Fatimah, F.N. (2013). Penggunaan Media Benda Konkret pada Tema Lingkungan untuk Peningkatan Hasil Belajar Siswa di Sekolah Dasar. JPGSD. 1 (2), 3.

Masjudin. (2016). Pembelajaran Kooperatif Investigatif Untuk Meningkatkan Pemahaman Siswa Materi Barisan Dan Deret. Jurnal Edukasi Matematika dan Sains, 4 (2), 78.

Mustofa, A., Slameto, dan Radia, E. (2018). Penerapan Model Group Investigation Berbantuan Media Video untuk Meningkatkan Hasil Belajar IPS Kelas IV SD. Kalam Cendekia, 6 (2.1), 28.

Primasari, E. (2017). Peningkatan Keaktifan dan Hasil Belajar Kognitif IPA melalui Group Investigation di SD Negeri 3 Sirau. Jurnal Pendidikan Guru Sekolah dasar, $10(6), 940$.

Sugiyono. (2012). Metode Penelitian Kuantitatif, Kualitatif, dan R\&D. Bandung: Alfabeta.

Susanto, A. (2014). Pengembangan Pembelajaran IPS di Sekolah Dasar. Jakarta : Kencana Prenadamedia.

Taniredja, A., Faridli, M., dan Harmianto, S. (2014). Model-Model Pembelajaran Inovatif dan Efektif. Bandung: alfabeta.

Tembang, T., Harmawati, D., Raharjaan, J.P., (2019). Peningkatan Hasil Belajar IPA Siswa Melalui Penerapan Model Pembelajaran Kooperatif Tipe Group Investigation di Sekolah Dasar. Jurnal IImiah Sekolah Dasar, 3 (2), 236.

Yuliana \& Budianti. (2015). Pengaruh Penggunaan Media Konkret terhadap Hasil Belajar Siswa Padamata Pelajaran Matematika Kelas II Sekolah Dasar Negeri Babelan Kota 06 Kecamatan Babelan Kabupaten Bekasi. Pedagogik, 3 (1), 36. 